\title{
Formation of Archaean felsic continental crust in the western Dharwar Craton, India: Isotopic and trace element constraints from detrital zircons
}

\author{
ARATHY RAVINDRAN ${ }^{1}$, KLAUS MEZGER ${ }^{2}$, \\ BALAKRISHNAN SRINIVASAN ${ }^{3}$, SAMEER RANJAN ${ }^{4}$, \\ DEWASHISH UPADHYAY ${ }^{4}$ AND JASPER BERNDT $^{5}$ \\ ${ }^{1}$ ETH Zürich \\ ${ }^{2}$ University of Bern \\ ${ }^{3}$ Pondicherry University \\ ${ }^{4}$ Indian Institute of Technology Kharagpur \\ ${ }^{5}$ University of Münster \\ Presenting Author: arathy.ravindran@erdw.ethz.ch
}

Formation of Archaean felsic continental crust in the western Dharwar Craton, India: Isotopic and trace element constraints from detrital zircons

Knowledge on the origin and evolution of the Archaean continental crust is limited due to the scarcity of pristine and exposed old crustal rock sequences. Due to the limitation imposed by metamorphosed rocks in preserving their primary geochemical signatures, it is relevant to study ancient grains of zircon that can provide valuable constraints on the nature and isotopic composition of their precursor felsic rocks at the time of mineral growth. Such grains can be preserved as xenocrysts in magmatic rocks or as detrital grains in sediments. Detrital zircons from different sedimentary rocks in the Western Dharwar Craton $(\sim 3.4 \mathrm{Ga})$ contain evidence of crustal relics as old as 3.6 $\mathrm{Ga}$. Pb-loss in these grains can result in incorrect age assignments for zircon growth and thus the initial Hf isotopic composition (e.g. Fisher \& Vervoort, 2018) of individual zircon grains was examined by choosing the best preserved regions of zircons using cathodoluminescence and backscattered electron images before analysis. In addition, only grains with higher (igneous, in most cases) $\mathrm{Th} / \mathrm{U}$ were considered. Initial $\mathrm{Hf}$ isotopes of the detrital zircon grains indicate the absence of significant evolved/felsic continental crust prior to $3.6 \mathrm{Ga}$. An average $\varepsilon \mathrm{Hf}_{\mathrm{i}}=+4.1 \pm 0.2$ suggests derivation of the host material from a source that was significantly depleted at $3.6 \mathrm{Ga}$.

Trace element abundances of 3.6-3.3 Ga old felsic magmatic rocks and detrital zircon grains indicate formation of intermediate to felsic melts at low to medium pressure conditions from an amphibolite-rich source. Some of the oldest TTGs with enriched HREE, indicate formation by shallow melting of a basaltic source rock. Granitoids formed after $\sim 3.25$ Ga have high $\mathrm{La} / \mathrm{Yb}$ and $\mathrm{Zr} / \mathrm{Sm}$ indicating their formation at high pressure (eclogite facies?) conditions. Thus $3.25 \mathrm{Ga}$ might mark the initiation of convergent-type plate tectonics (e.g. Hawkesworth et al., 2019).

[1] Fisher, C. \& Vervoort, J. (2018) Earth and Planetary Science Letters 488, 79-91.

[2] Hawkesworth, C., Cawood, P. \& Dhuime, B. (2019) Geoscience Frontiers 10, 165-173. 